\title{
Product Relationship Type Code
}

National Cancer Institute

\section{Source}

National Cancer Institute. Product Relationship Type Code. NCI Thesaurus. Code 695385.

A coded value specifying the product relationship type. 